\title{
Kemampuan pemecahan masalah matematika pada soal open ended materi lingkaran berdasarkan kemampuan awal matematika siswa
}

\author{
Tri Rahayu Agustina1*, Sri Subarinah², Nurul Hikmah², \\ Amrullah²
}

\author{
${ }^{1}$ Mahasiswa Pendidikan Matematika, FKIP, Universitas Mataram, Mataram \\ ${ }_{2}^{2}$ Pendidikan Matematika, FKIP, Universitas Mataram, Mataram
}

rahayutri668@gmail.com

Diterima: 26-09-2021; Direvisi: 29-09-2021; Dipublikasi: 30-09-2021

\begin{abstract}
The research was aims to describe the problem solving in mathematics ability on open ended with circle material based on the early mathematical ability of the students at 9th grade junior high school 8 mataram. The type of the research is a descriptive study with quantitative approach. The research subject are 28 students which selected with purposive sampling. The subject is grouped according to early abilities of high, moderate, and low mathematics using the midterms. The data-collection method used is an open-ended problem-solving test on a loop of 2 terms of description and interview methods. The results were analyzed based on an indicator of problem solving capability according to Polya. Based on the data analysis, student problem solving capabilities with advanced mathematical abilities fall into good category, averaged 79.69. The student problem-solving capability with the early math skills is in good category, with an average score of 77.50. Student problem solving with early abilities of low math falls in the less category, with an average value of 48.30. The students with advanced math skills and are filling indicators of understanding the problem, planning a settlement and carrying out a completion plan, but have not yet met the checking indicator.
\end{abstract}

Keywords: problem solving ability; open ended questions; Polya

\begin{abstract}
Abstrak
Penelitian ini bertujuan untuk mendeskripsikan kemampuan pemecahan masalah matematika pada soal open ended materi lingkaran berdasarkan kemampuan awal matematika siswa kelas IX SMP Negeri 8 Mataram. Jenis penelitian ini adalah penelitian deskriptif dengan pendekatan kuantitatif. Adapun subjek penelitian yaitu 28 siswa yang dipilih dengan purposive sampling. Subjek dikelompokkan berdasarkan kemampuan awal matematika tinggi, sedang, dan rendah dengan menggunakan hasil UTS. Metode pengumpulan data yang digunakan yaitu metode tes berupa tes pemecahan masalah open ended pada materi lingkaran yang terdiri dari 2 soal uraian dan metode wawancara. Hasil tes dianalisis berdasarkan indikator kemampuan pemecahan masalah menurut Polya. Berdasarkan hasil analisis data, kemampuan pemecahan masalah siswa dengan kemampuan awal matematika tinggi berada pada kategori baik, dengan nilai rata-rata 79,69. Kemampuan pemecahan masalah siswa dengan kemampuan awal matematika sedang berada pada kategori baik, dengan nilai rata-rata 77,50. Kemampuan pemecahan masalah siswa dengan kemampuan awal matematika rendah berada pada kategori kurang, dengan nilai rata-rata 48,30. Siswa dengan kemampuan awal matematika tinggi dan sedang memenuhi indikator memahami masalah, merencanakan penyelesaian dan melaksanakan rencana penyelesaian, namun belum memenuhi indikator memeriksa kembali.
\end{abstract}

Kata Kunci: kemampuan pemecahan masalah; soal open ended; Polya 


\section{PENDAHULUAN}

Dalam proses pembelajaran maupun dalam kehidupan sehari-hari, kemampuan pemecahan masalah memiliki peran yang sangat penting dalam berbagai bidang ilmu khususnya mata pelajaran matematika, karena dapat melatih siswa untuk berpikir dalam memecahkan masalah serta dapat meningkatkan aktivitas belajar siswa. Sehingga kemampuan pemecahan masalah matematika harus dimiliki oleh setiap siswa (Kartika et al., 2018). Kemampuan pemecahan masalah merupakan suatu kemampuan yang harus dimiliki dan dikembangkan oleh siswa agar mampu memecahkan suatu masalah matematika (Sapitri et al., 2019). Siswa dikatakan mampu memecahkan masalah matematika apabila siswa memahami masalah yang sedang dihadapi, dapat menentukan strategi yang tepat, kemudian menerapkannya dalam penyelesaian masalah. Oleh karena itu, siswa perlu dibiasakan dengan pemberian soalsoal matematika untuk meningkatkan kemampuan siswa dalam menyelesaikan masalah.

Hasil wawancara yang dilaksanakan tanggal 10 Desember 2019 pada salah satu guru mata pelajaran matematika di SMP Negeri 8 Mataram, soal-soal yang diberikan kepada siswa pada umumnya yaitu soal-soal yang berpedoman pada modul maupun buku paket yang hanya mempunyai satu jawaban benar atau close ended problem. Jarang sekali guru memberikan soal matematika kepada siswa yang menuntut penyelesaian berbeda atau prosedural berbeda atau biasa disebut dengan open ended problem. Hal tersebut disebabkan oleh keterbatasan waktu yang dimiliki guru dalam membuat soal-soal terbuka atau open ended problem. Akibatnya kemampuan siswa dalam memecahkan masalah tidak berkembang secara optimal.

Berdasarkan hasil observasi peneliti selama melaksanakan Program Pengalaman Lapangan (PPL) di kelas VIII SMP Negeri 8 Mataram tahun pelajaran 2019/2020, sebagian siswa masih mengalami kesulitan pada saat menyelesaikan soal matematika. Hal tersebut dapat dilihat pada hasil ulangan tengah semester siswa yang menunjukkan ketuntasan belajar secara klasikal pada setiap kelas berada dibawah ketuntasan klasikal yang sudah ditetapkan oleh sekolah, yaitu minimal $85 \%$.

Dengan fakta tersebut, siswa harus lebih sering diberikan soal-soal matematika sehingga dapat meningkatkan kemampuan siswa dalam menyelesaikan masalah. Salah satunya yaitu dengan memberikan soal yang tidak hanya terpaku pada satu proses penyelesaian atau biasa disebut dengan soal open ended dengan harapan siswa mampu menuangkan ide-ide sesuai dengan pemahaman yang dimiliki. Pemberian soalsoal tertutup atau soal yang memiliki penyelesaikan tunggal kurang memacu peningkatan kemampuan pemecahan masalah pada siswa. Oleh karena itu, siswa perlu dilatih untuk mengerjakan soal-soal open ended (Mariam et al., 2019).

Salah satu materi sering digunakan dalam kehidupan sehari-hari yaitu materi lingkaran. Lingkaran merupakan materi dasar yang berkaitan dengan materi matematika lainnya yang akan dipelajari pada jenjang berikutnya, misalnya bangun ruang sisi lengkung. Maka dari itu, penguasaan siswa terhadap materi lingkaran harus diperhatikan dengan baik. Apabila penguasaan siswa pada materi lingkaran masih kurang, siswa akan mengalami kesulitan untuk mempelajari materi selanjutnya.

Kemampuan pemecahan masalah yang rendah selain karena jarangnya penggunaan soal open ended, juga disebabkan oleh kemampuan awal siswa yang rendah pula. Kemampuan awal siswa penting untuk diketahui oleh guru sebelum memulai pembelajaran, sehingga guru dapat mengetahui sejauh mana siswa mengetahui materi 
yang akan di sajikan. Setiap siswa memiliki kemampuan awal yang berbeda-beda sesuai dengan kemampuan yang dimilikinya dalam proses belajar matematika (Razak, 2017).

Berdasarkan uraian di atas, maka peneliti tertarik untuk melakukan penelitian tentang "Kemampuan Pemecahan Masalah Matematika Pada Soal Open Ended Materi Lingkaran Berdasarkan Kemampuan Awal Matematika Siswa Kelas IX SMP Negeri 8 Mataram".

\section{METODE PENELITIAN}

Jenis penelitian yang digunakan dalam penelitian ini yaitu penelitian deskriptif dengan pendekatan kualitatif. Penelitian deskriptif merupakan suatu metode penelitian yang menggambarkan kegiatan-kegiatan yang dilakukan terhadap objek-objek tertentu dengan cara sistematis dan jelas (Hamdi \& Baharuddin, 2014).

Penelitian ini dilakukan di SMP Negeri 8 Mataram tahun pelajaran 2020/2021. Adapun yang menjadi subjek penelitian adalah 28 siswa dengan perincian 18 siswa dari kelas IX D dan 10 siswa dari kelas IX E di SMP Negeri 8 Mataram. Pemilihan subjek dalam penelitian ini dilakukan dengan cara purposive sampling. Purposive sampling merupakan teknik pengambilan sampel dengan mempertimbangkan hal-hal tertentu (Kristofora \& Sujadi, 2017). Pertimbangan yang dimaksudkan dalam penelitian ini yaitu kelas yang paling heterogen dibandingkan dengan kelas yang lainnya, yaitu kelas yang memiliki siswa dengan kemampuan awal matematika tinggi, kemampuan awal matematika sedang dan kemampuan awal matematika rendah.

Data yang digunakan dalam penelitian ini adalah data primer, yaitu data yang diperoleh langsung dari subjek penelitian (Sugiyono, 2014). Adapun teknik pengumpulan datanya yaitu tes kemampuan pemecahan masalah matematika dan wawancara. Pedoman wawancara digunakan kepada subjek penelitian setelah menyelesaikan soal tes kemampuan pemecahan masalah yang diberikan. Tes kemampuan pemecahan masalah terdiri dari 2 soal open ended dengan materi lingkaran. Tes yang digunakan telah divalidasi oleh dosen ahli. Setelah tes dilaksanakan, selanjutnya dilakukan analisis data berdasarkan rubrik penilaian kemampuan pemecahan masalah matematika siswa.

Tabel 1. Rubrik Penilaian Kemampuan Pemecahan Masalah

\begin{tabular}{|c|c|c|}
\hline $\begin{array}{c}\text { Tahap } \\
\text { pemecahan } \\
\text { masalah }\end{array}$ & Deskripsi & Skor \\
\hline \multirow{4}{*}{$\begin{array}{l}\text { Memahami } \\
\text { masalah } \\
\text { (understand } \\
\text { the problem) }\end{array}$} & $\begin{array}{l}\text { Menuliskan dengan benar apa yang diketahui dan apa yang } \\
\text { ditanyakan pada soal }\end{array}$ & 3 \\
\hline & $\begin{array}{l}\text { Menuliskan apa yang diketahui dan apa yang ditanyakan } \\
\text { pada soal, tetapi kurang tepat/lengkap }\end{array}$ & 2 \\
\hline & $\begin{array}{l}\text { Menuliskan apa yang diketahui dan/atau apa yang } \\
\text { ditanyakan pada soal tetapi kurang tepat }\end{array}$ & 1 \\
\hline & $\begin{array}{l}\text { Tidak menuliskan apa yang diketahui dan apa yang } \\
\text { ditanyakan }\end{array}$ & 0 \\
\hline Membuat & Merencanakan penyelesaian masalah dengan menuliskan & 3 \\
\hline
\end{tabular}




\begin{tabular}{|c|c|c|}
\hline $\begin{array}{l}\text { Tahap } \\
\text { pemecahan } \\
\text { masalah }\end{array}$ & Deskripsi & Skor \\
\hline \multirow{4}{*}{$\begin{array}{l}\text { rencana } \\
\text { (deviese } \\
\text { a plan) }\end{array}$} & $\begin{array}{l}\text { aturan matematika (rumus) dengan benar dan lengkap } \\
\text { sehingga mengarah ke jawaban yang benar }\end{array}$ & \\
\hline & $\begin{array}{l}\text { Merencanakan penyelesaian masalah dengan menuliskan } \\
\text { aturan matematika (rumus) dengan benar tetapi tidak } \\
\text { lengkap atau kurang tepat sehingga mengarah kejawaban } \\
\text { yang salah }\end{array}$ & 2 \\
\hline & $\begin{array}{l}\text { Salah menuliskan aturan matematika (rumus) yang } \\
\text { digunakan }\end{array}$ & 1 \\
\hline & $\begin{array}{l}\text { Tidak menuliskan aturan matematika (rumus) yang } \\
\text { digunakan }\end{array}$ & 0 \\
\hline \multirow{5}{*}{$\begin{array}{l}\text { Melaksanak } \\
\text { an rencana } \\
(\text { carry out } \\
\text { the plan) }\end{array}$} & $\begin{array}{l}\text { Menyelesaikan dengan prosedur yang benar dan sesuai } \\
\text { dengan rencana yang telah dibuat, melakukan perhitungan } \\
\text { dengan benar. }\end{array}$ & 4 \\
\hline & $\begin{array}{l}\text { Menyelesaikan dengan prosedur yang benar dan sesuai } \\
\text { dengan rencana yang telah dibuat akan tetapi salah dalam } \\
\text { melakukan perhitungan atau menyelesaikan sesuai } \\
\text { rencana yang telah dibuat dan dengan prosedur yang tepat } \\
\text { serta tidak melakukan kesalahan perhitungan namun } \\
\text { langkah pengerjaannya belum lengkap }\end{array}$ & 3 \\
\hline & $\begin{array}{l}\text { Menyelesaikan sasuai dengan rencana yang telah dibuat, } \\
\text { dengan prosedur yang kurang tepat dan salah dalam } \\
\text { melakukan perhitungan }\end{array}$ & 2 \\
\hline & $\begin{array}{l}\text { Menyelesaikan dengan prosedur yang tidak tepat dan tidak } \\
\text { sesuai dengan rencana yang telah disusun }\end{array}$ & 1 \\
\hline & Tidak ada penyelesaian sama sekali & 0 \\
\hline \multirow{3}{*}{$\begin{array}{l}\text { Melihat } \\
\text { kembali } \\
\text { (looking } \\
\text { back) }\end{array}$} & $\begin{array}{l}\text { Menuliskan kesimpulan dengan benar dan pengecekan } \\
\text { jawaban dengan tepat }\end{array}$ & 2 \\
\hline & $\begin{array}{l}\text { Menuliskan kesimpulan dan pengecekan jawaban yang } \\
\text { kurang tepat, menuliskan kesimpulan saja atau melakukan } \\
\text { pengecekan jawaban saja }\end{array}$ & 1 \\
\hline & Tidak menuliskan kesimpulan dan pengecekan jawaban & 0 \\
\hline
\end{tabular}

Untuk interpretasi kemampuan pemecahan masalah yang diadopsi dari penskoran menurut Arikunto (2013) disajikan pada Tabel 2 berikut.

Tabel 2. Interpretasi Kemampuan Pemecahan Masalah Matematika

\begin{tabular}{ccc}
\hline No. & Nilai & Kategori \\
\hline 1 & $80 \leq \mathrm{x} \leq 100$ & Baik sekali \\
2 & $66 \leq \mathrm{x}<80$ & Baik \\
3 & $56 \leq \mathrm{x}<66$ & Cukup \\
4 & $40 \leq \mathrm{x}<56$ & Kurang \\
5 & $0 \leq \mathrm{x}<40$ & Kurang sekali \\
\hline
\end{tabular}

\section{HASIL DAN PEMBAHASAN}

Penelitian ini dilakukan untuk mengetahui kemampuan pemecahan masalah matematika siswa dalam menyelesaikan soal open ended berdasarkan kemampuan awal matematika siswa. Rincian kegiatan yang dilakukan pada saat penelitian yaitu 
pada tanggal 26 November 2020, sebanyak 28 siswa diberikan tes pemecahan masalah matematika soal open ended. Selanjutnya siswa dikelompokkan berdasarkan kemampuan awal matematika tinggi, sedang dan rendah yang dilihat dari nilai ulangan tengah semester.

Hasil pengelompokkan siswa berdasarkan kemampuan awal matematika yang dilihat hari hasil ulangan tengah semester diperoleh banyak siswa yang memiliki kemampuan awal matematika tinggi yaitu 4 orang, siswa yang memiliki kemampuan awal matematika sedang yaitu 5 orang dan siswa yang memiliki kemampuan awal matematika rendah yaitu 19 orang.

Penilaian terhadap hasil tes pemecahan masalah matematika siswa kelas IX SMP Negeri 8 Mataram dalam menyelesaikan soal open ended akan dihitung menggunakan rubrik penilaian kemampuan pemecahan masalah yang terdapat pada Tabel 1. Selanjutnya untuk penentuan kategori kemampuan pemecahan masalah matematika siswa mengacu pada interpretasi kemampuan pemecahan masalah matematika pada tabel 2. Sehingga diperoleh kategori kemampuan pemecahan masalah matematika pada setiap tahap berdasarkan kemampuan awal matematika sebagai berikut.

Tabel 3. Kemampuan Pemecahan Masalah pada Setiap Tahap dalam Menyelesaikan Soal Open Ended Materi Lingkaran Berdasarkan Kemampuan Awal Matematika

\begin{tabular}{|c|c|c|c|c|c|c|c|}
\hline \multirow{3}{*}{ No } & \multirow{3}{*}{$\begin{array}{l}\text { Tahap-tahap } \\
\text { kemampuan } \\
\text { pemecahan } \\
\text { masalah }\end{array}$} & \multicolumn{6}{|c|}{ Kemampuan Awal Matematika } \\
\hline & & \multicolumn{2}{|c|}{ Tinggi } & \multicolumn{2}{|c|}{ Sedang } & \multicolumn{2}{|c|}{ Rendah } \\
\hline & & $\begin{array}{l}\text { rata- } \\
\text { rata }\end{array}$ & Kategori & $\begin{array}{l}\text { rata- } \\
\text { rata }\end{array}$ & kategori & $\begin{array}{l}\text { rata- } \\
\text { rata }\end{array}$ & kategori \\
\hline 1 & $\begin{array}{c}\text { Memahami } \\
\text { masalah }\end{array}$ & 95,83 & $\begin{array}{c}\text { baik } \\
\text { sekali }\end{array}$ & 90 & $\begin{array}{c}\text { baik } \\
\text { sekali }\end{array}$ & 68,42 & Baik \\
\hline 2 & $\begin{array}{c}\text { Merencanakan } \\
\text { penyelesaian }\end{array}$ & 91,67 & $\begin{array}{l}\text { baik } \\
\text { sekali }\end{array}$ & 100 & $\begin{array}{l}\text { baik } \\
\text { sekali }\end{array}$ & 64,91 & cukup \\
\hline 3 & $\begin{array}{c}\text { Melaksanakan } \\
\text { rencana }\end{array}$ & 100 & $\begin{array}{c}\text { baik } \\
\text { sekali }\end{array}$ & 100 & $\begin{array}{c}\text { baik } \\
\text { sekali }\end{array}$ & 51,32 & kurang \\
\hline 4 & $\begin{array}{c}\text { Memeriksa } \\
\text { kembali }\end{array}$ & 31,25 & $\begin{array}{c}\text { kurang } \\
\text { sekali }\end{array}$ & 20 & $\begin{array}{l}\text { kurang } \\
\text { sekali }\end{array}$ & 7,89 & $\begin{array}{c}\text { kurang } \\
\text { sekali }\end{array}$ \\
\hline
\end{tabular}

\subsection{Kemampuan Pemecahan Masalah Siswa dengan Kemampuan Awal Matematika Tinggi}

Siswa dengan kemampuan awal matematika tinggi tidak mengalami kesulitan dalam memahami masalah, dapat menuliskan informasi-informasi yang diketahui dan ditanyakan pada soal dengan benar. Subjek dapat memahami masalah dengan baik jika dapat melihat atau menuliskan unsur-unsur yang diketahui dan yang ditanyakan pada masalah yang diajukan (Akramunnisa \& Sulestry, 2016).

Selanjutnya pada tahap merencanakan penyelesaian, siswa dengan kemampuan awal matematika tinggi mampu menggunakan semua informasi yang terdapat pada soal untuk memecahkan masalah serta dapat menentukan antara informasi yang ada pada 
soal sehingga mampu menentukan langkah yang digunakan dala menyelesaikan soal open ended tersebut.

Pada tahap melaksanakan rencana penyelesaian, siswa sudah mampu menjelaskan dan melaksanakan rencana penyelesaian yang telah ditentukan sebelumnya serta mampu melakukan perhitungan dengan benar. Akramunnisa \& Sulestry (2016) mengungkapkan pada tahap melaksanakan rencana penyelesaian, subjek melakukan perhitungan sesuai dengan rencana yang telah dibuat berdasarkan aturan atau prinsip matematika.

Siswa dengan kemampuan awal matematika tinggi, mengetahui bahwa soal yang diberikan merupakan soal open ended. Hal tersebut diketahui dari hasil wawancara yang dilakukan, siswa mengatakan bahwa terdapat alternatif jawaban lain selain jawaban yang mereka tulis pada lembar jawaban. Siswa juga memahami dan mampu menyelesaikan jika diminta untuk menuliskan alternatif jawaban yang lain.

Pada tahap memeriksa kembali, siswa sudah mampu menuliskan kesimpulan dengan tepat namun tidak dapat menuliskan pengecekan kembali jawaban karena siswa tidak mengetahui cara melakukan pengecekan kembali jawaban yang sudah diperoleh. Tahap ini merupakan kategori paling rendah yang diperoleh siswa dibandingkan dengan tahap-tahap yang lain. Hal ini sejalan dengan pendapat Ariani et al. (2017), meskipun telah diminta untuk menuliskan pengecekan kembali terhadap proses dan hasil penyelesaian yang diperoleh, masih banyak siswa yang tidak mengerti cara melakukan pengecekan kembali pada soal yang diberikan.

\subsection{Kemampuan Pemecahan Masalah Siswa dengan Kemampuan Awal Matematika Sedang}

Siswa dengan kemampuan awal matematika sedang tidak mengalami kesulitan dalam memahami masalah, siswa dapat menuliskan informasi yang diketahui dan ditanyakan pada soal. Walaupun pada pengerjaan sebagian siswa tidak menuliskan beberapa informasi yang diketahui dan ditanyakan. Namun ketika dilakukan wawancara, siswa tersebut dapat menyebutkan informasi yang diketahui dan ditanyakan pada soal dengan benar. Siswa yang melakukan kesalahan dengan tidak menuliskan informasi yang diketahui dan ditanyakan pada soal tetapi bisa menyelesaikan tahap selanjutnya bukan berarti tidak memahami masalah, melainkan sudah terbiasa dalam menyelesaikan soal uraian dengan tidak menuliskan apa yang diketahui dan ditanyakan (Kristofora \& Sujadi, 2017).

Tahap merencanakan penyelesaian, siswa mampu menggunakan semua informasi yang terdapat pada soal untuk memecahkan masalah serta dapat menentukan keterkaitan antara informasi yang ada pada soal sehingga mampu menentukan langkah yang digunakan dalam menyelesaikan soal open ended tersebut. 
Pada tahap melaksanakan rencana atau strategi pemecahan masalah, siswa melanjutkan perhitungan dengan informasi-informasi yang ada sesuai dengan rencana penyelesaian yang telah dibuat sebelumnya (Nurhayati, 2013). Siswa dengan kemampuan awal matematika sedang pada penelitian ini, juga melakukan perhitungan sesuai dengan aturan atau rumus matematika yang telah direncanakan sebelumnya.

Siswa dengan kemampuan awal matematika sedang juga mengetahui bahwa soal yang diberikan merupakan soal open ended. Hal tersebut diketahui dari hasil wawancara yang dilakukan, siswa mengatakan bahwa terdapat alternatif jawaban lain selain jawaban yang mereka tulis pada lembar jawaban. Siswa juga memahami dan mampu menyelesaikan jika diminta untuk menuliskan alternatif jawaban yang lain.

Pada tahap memeriksa kembali, hampir semua siswa dengan kemampuan awal matematika sedang tidak melakukan pengecekan kembali jawaban mereka. Pernyataan tersebut didukung oleh pendapat Delyana (2015) dalam penelitiannya yang mengungkapkan bahwa dari hasi tes pemecahan masalah yang diberikan, sebagian besar siswa tidak melakukan pemeriksaan kembali terhadap jawaban yang diperoleh dan mereka tidak melakukan pengecekan kembali karena sudah menganggap jawaban mereka benar.

\subsection{Kemampuan Pemecahan Masalah Siswa dengan Kemampuan Awal Matematika Rendah}

Siswa dengan kemampuan awal matematika rendah tidak mengalami kesulitan dalam memahami masalah, dapat menuliskan informasi-informasi yang diketahui dan ditanyakan pada soal dengan benar meskipun siswa dengan kemampuan awal matematika rendah tidak menuliskan dengan lengkap informasi yang diketahui dan ditanyakan pada soal.

pada tahap merencanakan penyelesaian, siswa dengan kemampuan awal matematika rendah tidak mampu menggunakan semua informasi yang terdapat pada soal untuk memecahkan masalah. Hal ini senada dengan penelitian yang dilakukan oleh Subarinah et al. (2019), yang menyimpulkan bahwa mahasiswa dengan kemampuan matematika rendah tidak mampu menggeneralisasi suatu pola, yang artinya belum mampu menyusun rumus atau pola yang berkaitan dengan pola sebelumnya.

Siswa dengan kemampuan awal matematika rendah, sebagian siswa tidak mengetahui bahwa soal yang diberikan merupakan soal open ended. Hal tersebut diketahui dari hasil wawancara yang dilakukan, siswa mengatakan bahwa tidak terdapat alternatif jawaban lain selain jawaban yang mereka tulis pada lembar jawaban.

Pada tahap memeriksa kembali, siswa dengan kemampuan awal matematika rendah tidak mampu menarik kesimpulan serta melakukan pengecekan kembali terhadap jawaban yang mereka peroleh. Kesulitan siswa saat melihat kembali atau pada indikator pengecekan kembali, siswa tidak tau cara melakukan pengecekan kembali 
dengan benar. Siswa tidak dapat mengatur waktu pengerjaan dengan baik dan malas untuk melakukan pengecekan kembali (Purnamasari \& Setiawan, 2019).

\section{SIMPULAN}

Berdasarkan hasil penelitian dan pembahasan yang telah dipaparkan maka kesimpulan yang diperoleh kemampuan pemecahan masalah siswa dalam menyelesaikan soal open ended berdasarkan kemampuan awal matematika tinggi dan sedang memenuhi indikator memahami masalah, merencanakan menyelesaian dan melaksanakan rencana penyelesian, tetapi siswa belum memenuhi indikator memeriksa kembali. Sehingga kemampuan pemecahan masalah siswa berdasarkan kemampuan awal matematika tinggi dan sedang berada pada kategori baik. Nilai ratarata siswa dengan kemampuan awal matematika tinggi 79,69 , dan nilai rata-rata siswa dengan kemampuan awal matematika sedang 77,50.

Kemampuan pemecahan masalah siswa dengan kemampuan awal matematika rendah dalam menyelesaikan soal open ended berada pada kategori kurang, dengan nilai ratarata 48,30. Pada tahap memahami masalah mampu menentukan informasi yang diketahui dan ditanyakan pada soal. Pada tahap merencanakan penyelesaian, siswa kurang mampu menentukan langkah-langkah yang akan dilakukan dalam menyelesaikan masalah. Sehingga pada tahap melaksanakan rencana penyelesaian, sebagian siswa salah melakukan perhitungan karena rencana yang dibuat tidak relevan untuk memecahkan masalah tersebut. Selanjutnya tahap memeriksa kembali, siswa dengan kemampuan awal matematika rendah tidak menuliskan kesimpulan maupun pengecekan kembali terhadap jawaban yang mereka peroleh.

\section{REFERENSI}

Akramunnisa, \& Sulestry, A. I. (2016). Analisis kemampuan menyelesaikan masalah matematika ditinjau dari kemampuan awal tinggi dan gaya kognitif field independent (FI). Pedagogy Jurnal Pendidikan Matematika, 1(2), 46-56. http://dx.doi.org/10.30605/pedagogy.v1i2.355

Amran, Ikhsan, M., \& Dustri, M. (2016). Peningkatan kemampuan pemahaman dan komunikasi matematis siswa SMAN 3 Banda Aceh melalui penerapan model problem based learning. Jurnal Didaktik Matematika, 3(2), 75-84. repository.unsyiah.ac.id/DM/article/view/5644/4675

Ariani, S., Hartono, Y., \& Hiltrimartin, C. (2017). Kemampuan pemecahan masalah matematika siswa pada pembelajaran matematika menggunakan strategi abduktif-deduktif di SMA Negeri 1 Indralaya Utara. Jurnal Glemen, 3(1). https://repository.unsri.ac.id/21453

Arikunto, S. (2013). Dasar-dasar evaluasi Pendidikan. Jakarta: PT Bumi Aksara.

Delyana, H. (2015). Peningkatan kemampuan pemecahan masalah matematika siswa kelas vii melalui penerapan pendekatan open ended. LEMMA, 11(1), 26-34. https://doi.org/10.22202/j1.2015.v2i1.523

Hamdi, A. S., \& Baharuddin, E. (2014). Metode penelitian kuantitatif aplikasi dalam pendidikan. Sleman: Deepublish. 
Kartika, R., Rohaeti, E. E., \& Afrilianto, M. (2018). Analisis kemampuan pemecahan masalah matematik siswa SMP kelas vii pada materi persegi panjang. JPMI Jurnal Pembelajaran Matematika Inovatif, 1(4), 773-778. http://dx.doi.org/10.22460/jpmi.v1i4.p773-778

Mariam, S., Nurmala, N., Nurdianti, D., Rustyani, N., Desi, A., \& Hidayat, W. (2019). Analisis kemampuan pemecahan masalah matematis siswa MTsN dengan menggunakan metode open ended di Bandung Barat. Jurnal Cendekia, 3(1), 178-186. https://doi.org/10.31004/cendekia.v3i1.94

Nurhayati. (2013). Penerapan langkah-langkah Polya untuk meningkatkan hasil belajar siswa dalam menyelesaikan soal cerita himpunan di kelas vii SMP Nasional Wani. Jurnal Elektronik Pendidikan Matematika Tadulako, http:/jurnal.untad.ac.id/jurnal/index.php/JEPMT/article/view/3141/2211

Purnamasari, I., \& Setiawan, W. (2019). Kemampuan pemecahan masalah matematis siswa SMP pada materi SPLDV ditinjau dari kemampuan awal matematika. Journal of Medives, 3(2), 207-215. https://doi.org/10.31331/medivesveteran.v3i2.771

Razak, F. 2017. Hubungan Kemampuan Awal Terhadap Kemampuan Berpikir Kritis Matematika Pada Siswa Kelas VII SMP Pesantren Immim Putri Minasatene. Mosharafa, 6(1), 117-128. https://doi.org/10.31980/mosharafa.v6i1.299

Sapitri, Y., Utami, C., \& Mariyam. (2019). Analisis kemampuan pemecahan masalah siswa dalam menyelesaikan soal open ended pada materi lingkaran ditinjau dari minat belajar. Variabel, 2(1), 16-23 https://journal.stkipsingkawang.ac.id/index.php/jvar/article/view/ $1028 / 973$

Subarinah, S., Hikmah, N., \& Azmi, S. (2019). Analysis of student's mathematical investigation based on the variation of mathematical abilities. Proceedings of the 1st Annual Conference on Education and Social Sciences (ACCESS 2019), 465(1), 115-118. https://doi.org/10.2991/assehr.k.200827.030

Sugiyono. (2014). Memahami penelitian kualitatif. Bandung: Alfabeta.

Kristofora, M., \& Sujadi, A. A. (2017). Analisis kesalahan dalam menyelesaikan masalah matematika dengan menggunakan langkah Polya siswa kelas vii SMP. Jurnal PRISMA, 6(1), 9-16. https://jurnal.unsur.ac.id/prisma/article/view/24/15 